\title{
THE PETROLOGY OF THE WESSELTON KIMBERLITE SILLS, KIMBERLEY, CAPE PROVINCE, SOUTH AFRICA.
}

\author{
Shee ${ }^{(1)}$, S.R. and Clement ${ }^{(2)}$, C.R. \\ (1) Stockdale Prospecting Limited, South Yarra, Australia; \\ (2) Geology Dept. (Diamond Division), AAC, Johannesburg, RSA.
}

A major complex of kimberlite sills and associated dykes are exposed in water drainage galleries developed in country rocks at the 40 metre level surrounding the Wesselton Mine. They were discovered in 1976 by C.R. Clement, E.M.W. Skinner and L. Kleinjan of the Geology Department, DBCM Ltd.

The sills intrude the contact zone between the upper Dwyka shales (upper Carboniferous, 310 - 280 my) and a Karoo dolerite sill (195 - 135 my). It is apparant that the competent nature of the dolerite sills prevented the breakthrough of the kimberlite magma and promoted the formation of kimberlite sills (Hawthorne, 1968). The sill and dyke complex predates the pipe $(88.6+0.8 \mathrm{my}$; Smith, 1983a) and is cut by it. The sills are extensive and clement (1982) has estimated that prior to the emplacement of the pipe they extended over an area of 70 hectares. The sills have a maximum thickness of 5 metres but are generally < 1 metre thick (Hill, 1977). Individual sills range between a few centimetres and 0.5 metres in thickness and extend over horizontal distances of several hundred metres. Such features indicate the original presence of a highly mobile magma and baking of the adjacent shales testify to relatively high intrusion temperatures (Clement, 1982). The Wesselton sills display many of the structures recorded from the Benfontein complex by Dawson and Hawthorne (1973). These include prominent layering and magmatic sedimentation features.

Hill (1977) mapped two different types of hypabyssal facies kimberlites in the sill complex. The first variety is an altered aphanitic kimberlite containing rare macrocrysts. Sepentinised olivine phenocrysts are set in a fine grained matrix of calcite, phlogopite, spinel, ilmenite, perovskite, sepentine and apatite. Carbonate-rich segregations or diapirs in this kimberlite sill type have been described by Mitchell (1984). The second variety of kimberlite occurring in the sills is an unaltered macrocrystic kimberlite which contains small, scattered mantle derived harzburgite xenoliths, anhedral olivine macrocrysts and smaller, euhedral olivine phenocrysts set in a fine grained base. The matrix contains variable amounts of calcite, monticellite, phlogopite, spinel, ilmenite, perovskite, apatite and serpentine (Shee, 1985). The sills are Group 1 kimberlites (Smith, $1983 \mathrm{a}$ and b). Most of the dykes associated with the sill complex are altered, aphanitic varieties and can be correlated with the first type of sill kimberlite. Only a few of the dykes are fresh, macrocrystic kimberlites and correspond to the second type of sill kimberlite. The latter kimberlite type forms the subject of this study.

Whole rock geochemical analyses reveal that the macrocrystic sill kimberlites are less Mgo-rich $(18.9$ - 20.3 wt \%) than the macrocrystic main pipe kimberlites (27.1 - $33.4 \mathrm{wt} \%)$ at Wesselton. This is mainly a function of the relative paucity of anhedral olivine macrocryts in the sills $(8-11$ vol $\%)$ compared to the main pipe intrusions (26 - 33 vol \%). The relatively high $\mathrm{CaO}$ contents of the sill kimberlites (13.8 - 15 wt \%) compared to the main pipe kimberlites $(6.40-9.50 \mathrm{wt} \%)$ is reflected in the high modal abundance of groundmass monticellite $(22-32$ vol \%) in the former compared to the latter $(4-9$ vol $\%)$ (Shee, 1985). Olivine phenocryst cores in the sills have bimodal compositions but the rims have a common composition. Average compositions of the two core populations and rims are : 
1 : Fo 92.9, 0.38 wt $\%$ NiO, 0.10 wt $\% \mathrm{MnO}, \mathrm{CaO}$ not detected.

2 : Fo $86.5,0.25$ wt $\% \mathrm{NiO}, 0.17 \mathrm{wt} \div \mathrm{MnO}, 0.11 \mathrm{wt} \% \mathrm{CaO}$.

Rims : Fo 86.9, 0.17 wt $\% \mathrm{NiO}, 0.21$ wt $\% \mathrm{MnO}, 0.17$ wt $\% \mathrm{CaO}$.

Groundmass phlogopites in the sill kimberlites have higher mean TiO2 and ?ower mean MgO (2.29 wt $\%$ and 23.7 wt $\%$ respectively) than groundmass phlogopites from the main pipe intrusions (means 1.27 wt $\%$ TiO2 and 24.8 wt $\div \mathrm{MgO})$. The sill phlogopites have higher BaO contents $(0.05-5.55$, mean 1.37 wt \%) than the main pipe groundmass phlogopites (nd - 1.97, mean 0.30 wt \%). These features indicate that the sill phlogopites have crystallised from a relatively more evolved magma. The sill phlogopites have bimodal compositions with respect to $\mathrm{Al203}$ contents $(9-10$ and $14-18$ wt $\%)$ indicating two periods of phlogopite growth.

Orange, anhedral aluminous chromites with low TiO2 contents have similar compositions to orange fingerprint chromites in harzburgite xenoliths in the sill kimberlites and are thought to be xenocrysts derived from the disaggregation of such xenoliths. These xenocrysts are not in equilibrium with the kimberlite magma and have been mantled by opaque titanomagnetites which have similar compositions to those occurring as discrete euhedral crystals in the groundmass. Euhedral chromites and titanomagnetites occur as inclusions within olivine phenocrysts in the sill kimberlite, a feature which is not seen in the main pipe intrusions. The sill groundmass spinels show a normal kimberlite magmatic trend with a decrease in chromium and a progressive increase in TiO2, MgO, total $\mathrm{FeO}$ and $\mathrm{Fe}^{3+} / \mathrm{Fe}^{2+}$ as crystallisation proceeds. The $\mathrm{Fe}^{2+} / \mathrm{Fe}^{3+}$ ratios and $\mathrm{Al} 203$ contents remain nearly constant. The sill groundmass spinels evolve to more FeO, Fe2O3 and TiO2-rich compositions than those in the main pipe bodies. Heavy mineral concentrates of the sill kimberlite are mainly magnetites with minor titanomagnetites and a single chromite (Shee, 1985).

Ilmenite inclusions in olivine phenocrysts and groundmass ilmenites are less abundant in the sill kimberlites than in the main pipe intrusions. The sill ilmenites have high Mgo (10.94 - 12.55, mean 11.87 wt \%) and Cr203 $(3.25-5.65$, mean 4.58 wt $\%)$ contents. Ilmenites from heavy mineral concentrates of the sill kimberlites have similar compositions suggesting that the concentrate ilmenites are derived from the groundmass. The relatively MgO-poor compositions of the sill groundmass ilmenites compared to those in the main pipe intrusions can be attributed to crystallisation from a more fractionated magma.

The CaO contents of olivines is controlled by pressure (Simkin and Smith, 1970; Stormer, 1973), temperature (Finnerty and Boyd, 1978) and the CaO content of the magma (Watson, 1979). It is postulated that the first olivine phenocrysts crystallised under high pressure (within the upper mantle) and are magnesian (Fo 93) and do not contain detectable CaO in their cores. The kimberlite magma moved diapirically upwards and a second generation of olivine phenocrysts began to crystallise under relatively low pressures - perhaps during near surface intrusion. These phenocrysts are less magnesian (FO 86) compared to the early phenocrysts and contain detectable $\mathrm{CaO}$ in their cores. The relatively FeO-rich compositions of these phenocrysts is attributed to crystallisation from a relatively fractionated kimberlite magma and/or. to contemporaneous crystallisation of olivine and monticellite under low pressure. The CaO enrichment trend shown by the phenocryst rims is thought to be caused by reaction with residual magma that is progressively becoming more CaO-rich and/or by pressure release during magma emplacement. The whole rock compositions and the chemistry of olivine phenocrysts and groundmass phlogopite, ilmenite and spinel are all consistent with derivation from a fractionated kimberlite magma.

Clement (1982) suggested that precursor kimberlite dykes and sills play an important role in the subsequent development of kimberlite pipes. The early 
dykes and sills are intruded along near surface joints and fractures and upon crystallisation effectively "seal" the area. This "sealing" process is thought to be responsible for subsurface pressure build-up, for providing time for the development of precursor vapour phases to accumulate and, consequently, for the initiation of subsurface embryonic pipe-forming processes.

\section{References.}

Clement, C.R. (1982) A comparative geological study of some major kimberlite pipes in the Northern Cape and Orange Free State. Ph.D. thesis, University of Cape Town, South Africa.

Dawson, J.B. and Hawthorne, J.B. (1973) Magmatic sedimentation and carbonatitic differentiation in kimberlite sills at Benfontein, South Africa. Journal of the Geological Society, London, 129, 61-85.

Finnerty, T.A. and Boyd, F.R. (1978) Pressure dependent solubility of calcium in forsterite coexisting with diopside and enstatite. Carnegie Institute of Washington Yearbook, 77, 713717 .

Hawthorne, J.B. (1968) Kimberlite sills. Transactions of the Geological Society of South Africa, 71, 291-311.

Hill, D.R.H. (1977) Field relationships and petrography of the kimberlite sills and associated dykes at the 40 metre level of the Wesselton Mine, Kimberley, South Africa. B.Sc. Hons. thesis, University of Cape Town, South Africa.

Mitchell, R.H. (1984) Mineralogy and origin of carbonate-rich segregations in a composite kimberlite sill. Neues Jahrbuch Miner. Abh., 150, 2, 185-197.

Shee, S.R. (1985) The petrogenesis of the Wesselton Mine kimberlites, Kimberley, Cape Province, R.S.A. Ph.D. thesis, University of Cape Town, South Africa.

Simkin, T. and Smith, J.V. Minor element distribution in olivine. Journal of Geology, 78, 304-325.

Smith, C.B. (1983a) Pb, Sr, and Nd isotopic evidence for sources of southern African Cretaceous kimberlites. Nature, 304, 51-54.

Smith, C.B. (1983b) Rubidium-strontium, uranium-lead and samarium-neodymium isotopic studies of kimberlite and selected mantle derived xenoliths. Ph.D. thesis, University of the Witwatersrand, Johannesburg, R.S.A.

Stormer, J.C. (1973) Calcium zoning in olivine and its relationship to silica activity and pressure. Geochimica and Cosmochimica Acta. 37, 1815-1821. 